\title{
SHEA News
}

\section{The Society for Healthcare Epidemiology of America}

\begin{tabular}{|c|c|c|c|}
\hline PrESIDENT & Dale N. Gerding, MD & ACADEMIC COUNCILOR & Julie L. Gerberding, MD, MPH \\
\hline President-Elect & William Jarvis, MD & ACADEMIC COUNCILOR & Trish Perl, MD \\
\hline Vice President & Barry Farr, MD & Practice Councilor & Barbara Wade, MD \\
\hline Past President & John Boyce, MD & Practice Counchor & Alan Tice, MD \\
\hline SECRETARY & Larry J. Strausbaugh, MD & INIERNATIONAL COUNCILOR & Didier Pittet, MD \\
\hline TREASURER & Loreen A. Herwaldt, MD & & \\
\hline
\end{tabular}

\section{SHEA/ESGNI Training Course}

In November 1999, 60 medical doctors and ICPs from 14 European countries came to The Netherlands for the first SHEA/ESGNI (European Study Group of Nosocomial Infections) course in hospital epidemiology. The course was based on the successful SHEA/CDC course, but was adapted for Europe and enlarged to include topics such as molecular typing. Among the US and
European trainers (all SHEA members) were SHEA's and ESGNI's presidents, John Boyce and Emilio Bouza. In general, the course was rated as excellent and certainly achieved its primary goal, to give high-quality training at a reasonable price, without losing (or gaining) money. The next European course will be held in Geneva, Switzerland, in August 2000. Info: didier.pittet@hcuge.ch.

\section{Search for US Co-editor}

From the SHEA News editor: Some readers may have noticed that SHEA News, as well as the SHEA Newsletter, has quite a European touch. To be honest, the "touch" is more European than planned. When taking over from Dr. Batt, I assumed that receiving information would not be a problem, despite being located in Europe, since we are all connected by the World Wide Web. It would seem,

\section{Infections From Endoscopes}

An FDA and CDC Public Health Advisory reports several incidents in which patients developed serious infections after being examined with however, that there still is no substitute for having an old-fashioned "local affiliate" who can help ensure that news items are rounded up and sent through that modern connection. Is there a colleague in North America who would join us in this endeavor, for the modest glory of being named as a co-editor of SHEA News and the SHEA Newsletter? Please send e-mail to a.voss@mmb.azn.nl.

bronchoscopes that apparently were inadequately reprocessed in an automated endoscope reprocessor.

Further information on this problem, and the FDA and $\mathrm{CDC}$ recommendations that may help to reduce future incidents, can be found at http://www.fda.gov/cdrh/safety/end oreprocess.html.
Calendar

Feb 15-17. Forum on Respiratory Infections. Monte Carlo, Monaco. Info:http://www. aisc.it or respind@aisc.it.

Feb 24-25. Risk and Prevention. Paris, France. Info: http://www.rap2000.net.

Feb 29-Mar 4. Fifth World Congress on Trauma, Shock, Inflammation and Sepsis. Munich, Germany. Info: faist@gch.med.uni-muenchen.de.

Mar 5-9. 10th Annual Scientific Meeting of the Society for Healthcare Epidemiology of America in conjunction with the 4th Decennial International Conference on Nosocomial and HealthcareAssociated Infections. Atlanta, GA. Info: http://www.decennial.org.

Mar 27-31. Extension Training Program for Infection Control Practitioners. Iowa City, IA. Info: roscoe-porch@uiowa.edu. Apr 10-13. Ninth International Congress on Infectious Diseases. Buenos Aires, Argentina. Info: isidbos@aol.com.

Apr 17-19. Central Sterilising Club meeting. Cirencester, UK. Info: robertcspencer@ bristolphl.freeserve.co.uk.

May 3-5. 18th Annual Meeting of the European Society for Paediatric Infectious Disease, Neonatal Infections Antimicrobial Practice. Noordwijk, The Netherlands. Info: Y.Beeukkes@ mmb.azn.nl. 